\title{
An Investigation of Airborne Pollen in Taipei City, Taiwan, 1993-1994
}

\author{
Yueh-Lin Yang and Su-Hwa Chen* \\ Department of Botany, National Taiwan University, Taipei, Taiwan
}

A two-year aeropalynological study performed during January 14, 1993 to December 31, 1994 in Taipei City revealed 154 different pollen taxa, with the most frequent being Broussonetia (31.3\%), Trema (15\%), Bischofia (6.9\%), Mallotus (6.8\%), Cyathea (3.8\%), Morus (3.7\%), Fraxinus $(2.9 \%)$ and Gramineae $(2.8 \%)$, respectively. Two quantitative peaks of pollen grains appeared in March and in September in 1993, but only one peak in 1994. The dominant pollen taxa during these two peaks were Broussonetia and Mallotus. The heavy rain in February 1994 seemed to have delayed the first pollen peak to April, but Broussonetia was still the most frequent taxon. After July 1994, six typhoons brought heavy precipitation to northern Taiwan. Different weather types might have an effect on the concentration of airborne pollen grains, so that the timing of quantitative peaks was different in the two studied years. Arboreal pollen (AP), non-arboreal pollen (NAP) and fern spores (FS) constituted $81.7 \%, 7.7 \%$ and $7.8 \%$ of the two-year sum, respectively. AP dominated from January to June, NAP in November and fern spores in July. Native species in the Taipei Basin and trees along urban roadsides were the common sources of airborne pollen. The pollen calendar of two years in Taipei City was submitted.

Key words: Airborne pollen-Arboreal pollen-Fem spore - Non-arboreal pollen - Pollen calendar - Taipei

\section{Introduction}

Pollen-induced atopic diseases have become a serious problem for the last two decades (D'Amato and Liccardi 1994). For example, in many areas the most important causes of the allergic rhinitis include grasses (D'Amato and Spieksma 1990, Spieksma et al. 1995), ragweed (Rich 1994, Sriramarao and Subba Rao 1993), sugi (Sado and Takeshita 1991) and cypress (Pham et al. 1994). In Taiwan, pollen of Bermuda grass (Su et al. 1986) and rice (Tsai et al. 1990) were tested to be allergens. Recently developed methods of forecasting pollen concentrations could protect allergy suffers from exposure of pollen in advance (Arobba et al. 1992, Norris-Hill 1995). A pollen calendar, obtained from a conti-

* Corresponding author. E-mail: Suchen@coms.ntu.edu.tw Fax: 886-2-23918940 nuous aeropalynological survey, can provide many useful information for those aeroallergic studies (Johansen 1992, ínceoglu et al. 1994). The present study reports an investigation for the two-year pollen calendar on airborne pollen and spores in Taipei, the northern city of Taiwan, during 1993-1994.

\section{Materials and Methods}

A Burkard seven-day recording volumetric pollen trap was used for the trapping of airborne pollen grains over two years (1993-1994). The instrument was located on the flat roof of a nine-meter-high building in Hondau Junior High School in Taipei City $\left(25^{\circ} 03^{\prime} \mathrm{N}, 121^{\circ} 31^{\prime} \mathrm{E}\right)$ (Fig. 1).

The sampling air of 10 liters per min was checked once a week. Air was drawn through the instrument, where the particles were separated from the airstrip and recorded onto the tape of Burkard seven-day drum system. The continuous movement of the tape was pre-set at $2 \mathrm{~mm} / \mathrm{hr}$, so the total travel of the tape was $336 \mathrm{~mm}$ every week. The tape was cut into $48 \mathrm{~mm}$ long pieces and removed to glass slides, then the pollen grains and spores on it were identified, using an estimated sampling method of one transverse traverse per hour from trapping tap (Peng and Chen 1996).

The species of airborne pollen grains and spores were identified and photographed under a Leitz BM light microscope. The main references for identification included Pollen Flora of Taiwan (Huang 1972), Spore Flora of Taiwan (Huang 1981) and a SEM survey of airborne pollen grains in Taipei City (Chen 1988). Information about local floristic composition, flowering period, and altitudinal distribution were also considered.

Meteorological data (Fig. 2) were obtained from the Central Weather Bureau in Taipei. In 1993, the annual precipitation was $1,740.5 \mathrm{~mm}$. The average maximum and minimum temperatures in June and January were $29.6 \mathrm{C}$ and $14.8 \mathrm{C}$, respectively, with an annual average of $22.7 \mathrm{C}$. In 1994, the annual precipitation was $2,043.7 \mathrm{~mm}$. Average maximum and minimum temperatures were $29.6 \mathrm{C}$ and $16.3 \mathrm{C}$, respectively, with an annual average of $23.2 \mathrm{C}$.

Taipei City, situated in the northern part of Taiwan Island, is a urban area. The vegetation is located in city parks, avenue trees and gardens, and includes common native species. 


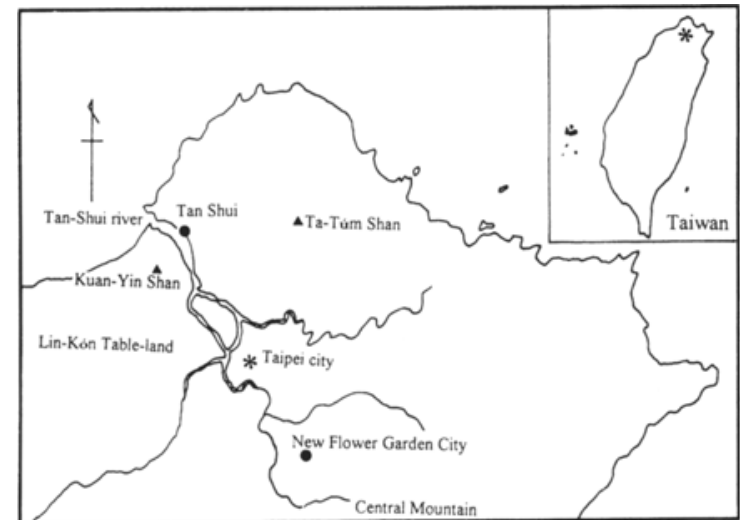

Fig. 1. Geographical location of Taipei city indicating the sampling site $(*)$.
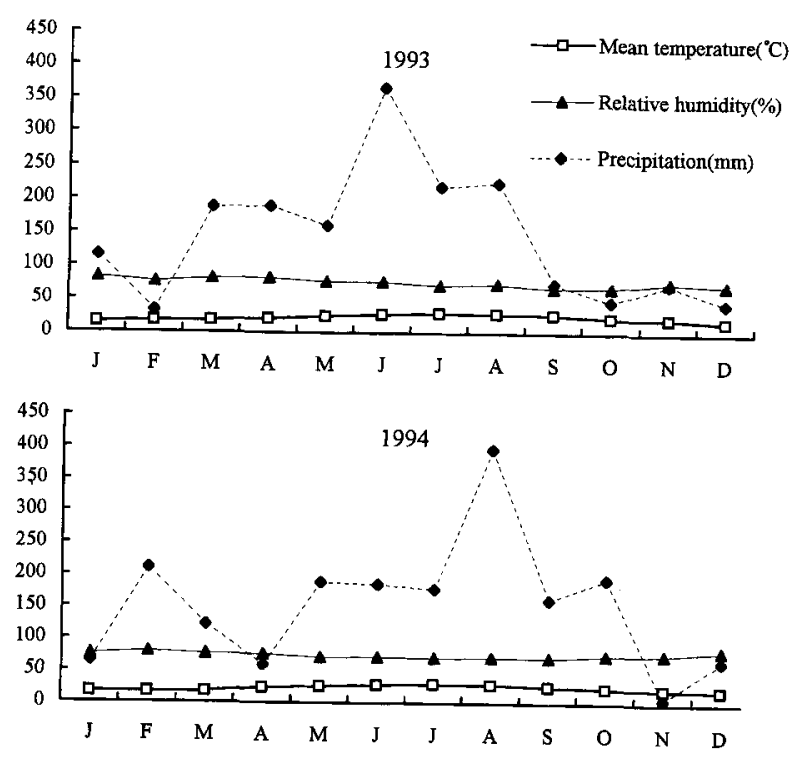

Fig. 2. Meteorological data in 1993 and 1994 in Taipei. (The data used are from Central Meteorological Bureau, Republic of China)

\section{Results}

\section{Airborne pollen components}

A total 54,263 and 73,620 airborne pollen grains and fern spores were identified and recorded in 1993 and 1994, respectively. A total of 154 different pollen and spore taxa, including 121 genera of angiospermous pollen grains, 5 genera of gymnospermous pollen grains and 28 genera of fern spores (Table 1). These accounted for $86.2 \%, 3.4 \%$ and $7.7 \%$ of the total during 1993 to $1994,2.7 \%$ could not be identified (Fig. 3).

The dominant airborne pollen types during these two years were Broussonetia (31.3\%), Trema (15\%), Bischofia $(6.9 \%)$, Mallotus $(6.8 \%)$, Cyathea $(3.8 \%)$, Morus $(3.7 \%)$, Fraxinus (2.9\%), Gramineae (2.8\%), Urticaceae (2.5\%), Juniperus $(1.9 \%)$, Artemisia (1.2\%), Humulus (1.2\%), Alnus (1\%), Macaranga (1\%) and Pinus (1\%) (Fig. 4).

The airborne pollen and fern spores were categorized into

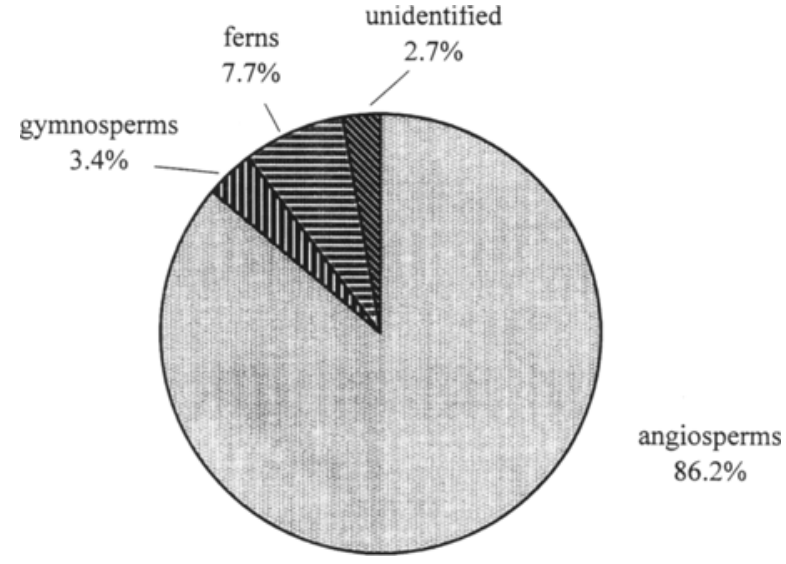

Fig. 3. Percentage of angiospermous pollen, gymnospermous pollen, fern spores and unidenified pollen in Taipei during 1993 and 1994.

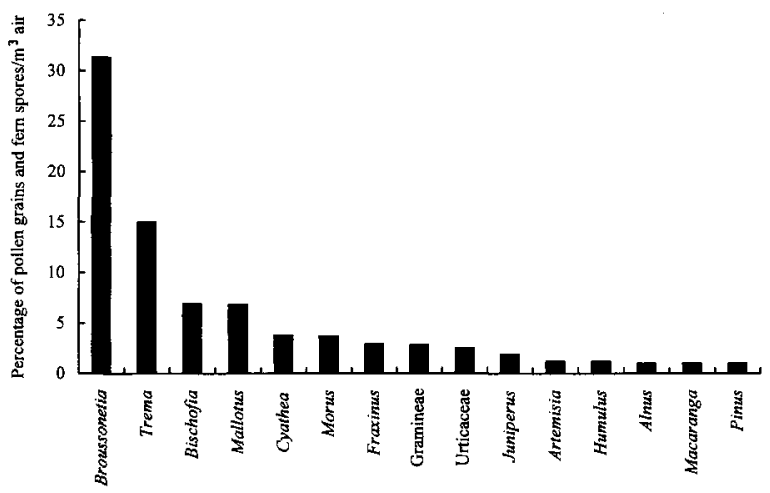

Fig. 4. The dominant airborne pollen taxa in Taipei during 1993 and 1994.

three groups: arboreal pollen (including trees and shrubs) (AP), non-arboreal pollen (NAP), and fern spores (FS). In this study, AP, NAP and FS constituted $81.7 \%, 7.7 \%$ and $7.8 \%$ of the two-year sum, respectively. AP dominated from Januany to June, NAP in November and FS in July (Fig. 5).

\section{Main pollen season}

In 1993, two definite pollen seasons appeared in March and in September (Fig. 6). The dominant pollen taxa during these two pollen seasons were Broussonetia and Mallotus, respectively. In 1994, the first pollen season was delayed to until April, but Broussonetia was still the most frequent taxon. No definite second pollen season appeared.

\section{Pollen calendar}

The pollen calendar in 1993 (Fig. 7) and 1994 (Fig. 8) included 26 and 25 dominant taxa, respectively. AP, NAP and FS consist of 20,6 and 4 taxa in those calendars, respectively. In spring (from February to April), the most important contributors were AP, such as Juniperus, Pinus, Salix, Morus, Bischofia, Celtis and Broussonetia. In summer (from May to July), the dominant pollen types were also AP, such as Cassia, Trema, Macaranga, Acacia, Ardisia and Fraxinus. 
Table 1. Pollen grains and fem spores taxa recorded in the atmosphere in Taipei during 1993 and 1994

\begin{tabular}{|c|c|c|c|c|c|}
\hline \multicolumn{6}{|c|}{ Angiospermous plant } \\
\hline Aceraceae & Acer & Juglandaceae & Juglans & Pittosporaceae & Pittosorum \\
\hline \multirow[t]{2}{*}{ Actinidiaceae } & Saurauia & Lauraceae & Cinnamomum & Plantaginaceae & Plantago \\
\hline & Actinidia & & Persea & Polygonaceae & Rumex \\
\hline Amacardiaceae & Rhus & Leguminosae & Acacia & Portulacaceae & Portulaca \\
\hline Apocynaceae & Nerium & & Cassia & Primulaceae & Lysimachia \\
\hline Aquifoliaceae & $\operatorname{llex}$ & & Crotalaria & Punicaceae & Punica \\
\hline Betulaceae & Alnus & & Erythrina & Ranunculaceae & Clematis \\
\hline \multirow[t]{2}{*}{ Bomacaceae } & Bombax & & Mimosa & & Ranunculus \\
\hline & Pachira & & Trifolium & Rosaceae & Thalictrum \\
\hline Boraginaceae & Cordia & Liliaceae & Asparagus & & Rhaphiolepis \\
\hline Caprifoliaceae & Viburnum & & Lilium & & Rubus \\
\hline Casuarinaceae & Casuarina & & Ophiopogon & Rubiaceae & others \\
\hline Chenopodiaceae & Chenopodium & & Smilax & & Ixora \\
\hline \multirow[t]{2}{*}{ Combretaceae } & Quisqualis & & others & & Lasianthus \\
\hline & Terminalia & Loranthaceae & & & Paederia \\
\hline Commelinaceae & Commelina & Lythraceae & Lawsonia & Rutaceae & Rubia \\
\hline \multirow[t]{10}{*}{ Compositae } & Ageratum & & Lagerstroemia & Salicaceae & Murraya \\
\hline & Ambrosia & Meliaceae & Aglaia & Sapindaceae & Salix \\
\hline & Artemisia & Melastomaceae & Melastoma & & Euphoria \\
\hline & Bidens & Moraceae & Broussonetia & & Litchi \\
\hline & Erechites & & Ficus & Saururaceae & Houttuynia \\
\hline & Erigeron & & Humulus & Saxifragaceae & Hyorangea \\
\hline & Gnaphalium & & Morus & Solanaceae & Datura \\
\hline & Siegesbeckia & Myricaceae & Myrica & & Solanum \\
\hline & Solidago & Myrsinaceae & Ardisia & Symplocaceae & Symplocos \\
\hline & others & & Maesa & Theaceae & Cleyera \\
\hline Convolvulaceae & loomoea & Myrtaceae & Eucalyptus & & Eurya \\
\hline Crassulaceae & Sedum & & Eugenia & & Thea \\
\hline Cyperaceae & & & Melaleuca & Typhaceae & Typha \\
\hline \multirow[t]{2}{*}{ Elaeocarpaceae } & Elaeocarpus & & Psidium & Ulmaceae & Aphananthe \\
\hline & Sloanea & & Syzygium & & Celtis \\
\hline \multirow[t]{8}{*}{ Euphorbiaceae } & Acalypha & Nyctaginaceae & Bouginvillea & & Trema \\
\hline & Bischofia & Nymphaeaceae & Nymphaea & & Zelkova \\
\hline & Euphorbia & Oleaceae & Fraxinus & Umbelliferae & Hydrocotyle \\
\hline & Macaranga & & Ligustrum & & Sanicula \\
\hline & Mallotus & & Osmanthus & & others \\
\hline & Ricinus & Oxalidaceae & Oxalis & Urticaceae & Pilea \\
\hline & Sapium & Palmae & Areca & & others \\
\hline & Phyllanthus & & Chrysalidocarpus & Verbenaceae & Callicarpa \\
\hline Fagaceae & & & Livistona & & Clerodendrum \\
\hline Flacourtiaceae & Scolopia & & Phoenix & & Premna \\
\hline Gramineae & & & Roystonea & Vitaceae & Vitis \\
\hline Hamamelidaceae & Liquidambar & Piperaceae & Peperomia & & \\
\hline Juglandaceae & Engelhardtia & & Piper & & \\
\hline \multicolumn{6}{|c|}{ Gymnospermous plant } \\
\hline Cupressaceae & Juniperus & Pinaceae & Pinus & Taxodiaceae & Cryptomeria \\
\hline Cycadaceae & Cycas & & Tsuga & & \\
\hline \multicolumn{6}{|c|}{ Fern } \\
\hline Adiantaceae & Adiantum & Dennstaedtiaceae & Microlepia & Marattiaceae & Angiopteris \\
\hline Aspidaceae & & & Pteridium & Oleandraceae & Nephrolepis \\
\hline Aspleniaceae & Asplenium & Docksoniaceae & Cibotium & Plagioyriaceae & Plagiogyria \\
\hline \multirow[t]{2}{*}{ Athyriaceae } & Athyriopsis & Dryopteridaceae & Acrophorus & Polypodiaceae & Lemmaphylium \\
\hline & Diplazium & & Arachniodes & Pteridaceae & Pteris \\
\hline Blechnaceae & Woodwardia & Dryopteridaceae & Dryopteris & Schizaeaceae & Lygodium \\
\hline Cyatheaceae & Cyathea & & Polystichum & Selaginellaceae & Selaginella \\
\hline Davalliaceae & Davallia & Gleicheniaceae & Diranopteris & Thelypteridaceae & Christella \\
\hline \multirow[t]{2}{*}{ Dennstaedtiaceae } & Dennstaedtia & Lindantaceae & Sphenomeris & & Phegopteris \\
\hline & Histiopteris & Lycopodiaceae & Lycopodium & & \\
\hline
\end{tabular}




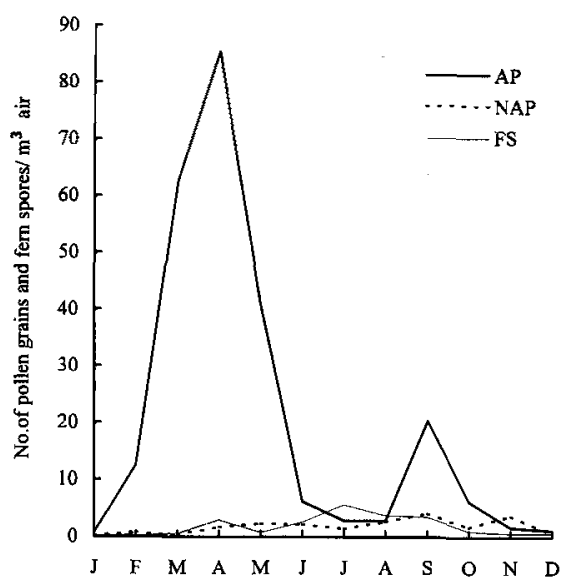

Fig. 5. Airborne pollen and fern spores of plant classified into three groups: AP (arboreal pollen), NAP (non-arboreal pollen) and FS (fern spores). The graph shows the average for the two years of monthly AP, NAP and FS counts during 1993 and 1994.

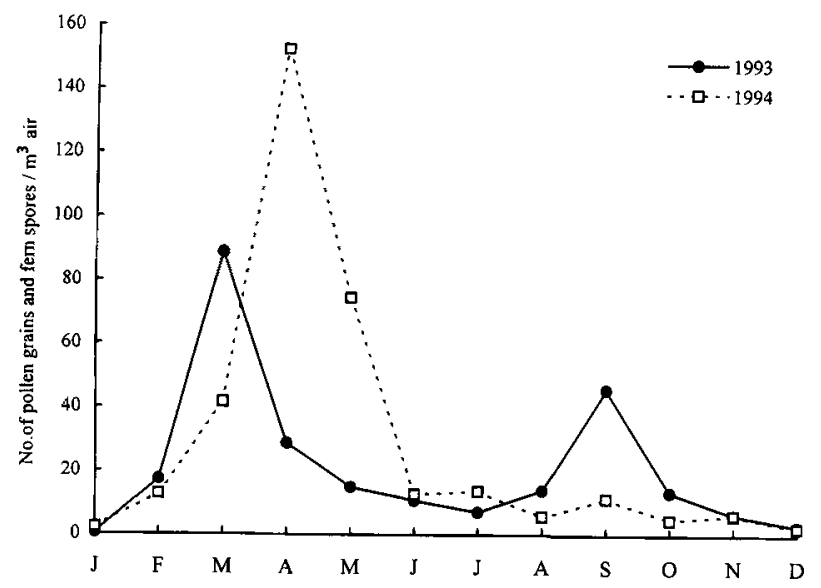

Fig. 6. Concentration of airborne pollen grains and fern spores in various months revealed the different pollen season types in 1993 and 1994.

NAP, such as Piper, Cyperaceae and Humulus, were also recorded in summer. In autumn (from August to October), FS and NAP, such as Cyathea, Microlepia, Gramineae, Artemisia and Ambrosia, were dominant. Airborne pollen grains of Gramineae were recorded throughout the year, but the highest concentration occurred in late autumn. AP, such as Mallotus, Alnus and Melaleuca, were also recorded in autumn. In winter (from November to January), small concentrations of airborne pollen, such as Cryptomeria, were recorded, remaining present in the air until next spring.

Some pollen types in individual calendars of the two years showed different concentrations. Small concentrations of Salix, Ambrosia, Microlepia, Melaleuca and Cryptomeria were recorded in 1994, while in 1993 small concentrations of Piper, Acacia and Diplazium occurred.
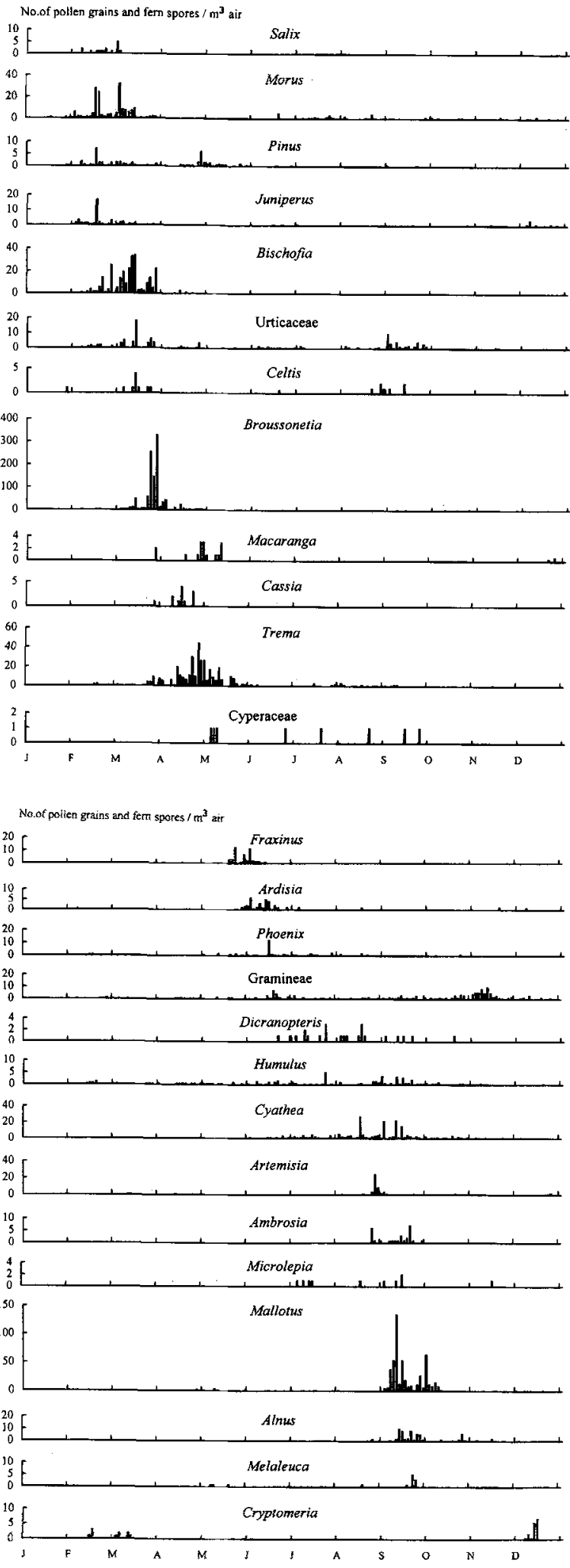

Fig. 7. Pollen calendar of 26 dominant taxa collected from the atmosphere of Taipei. The graph shows daily pollen counts in 1993. 

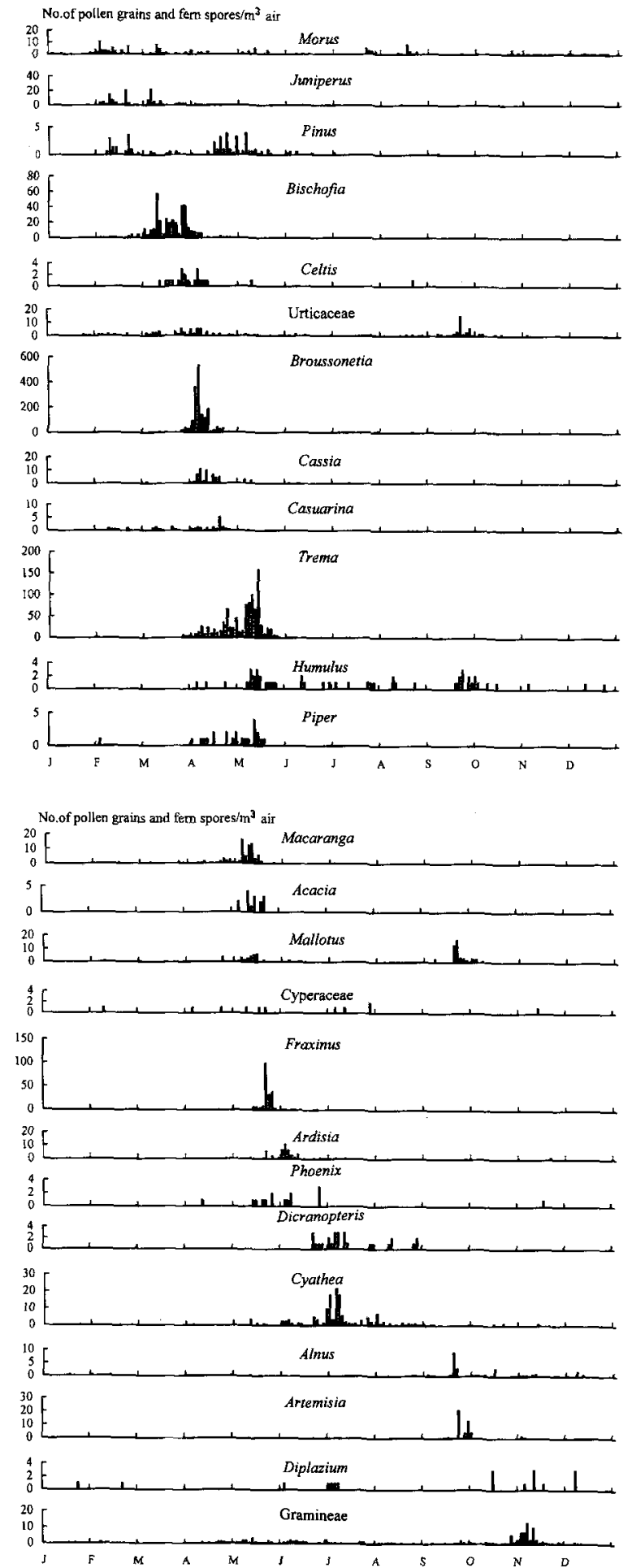

Fig. 8. Pollen calendar of 25 dominant taxa collected from the atmosphere of Taipei. The graph shows daily pollen counts in 1994.

\section{Discussion}

\section{Airborne pollen components}

Taipei, lies in a basin at a low altitude with vegetation influenced by excessive urbanization and biotic interference. However, the common sources of AP included native species, such as Mallotus japonicus, Mallotus paniculatus, Macaranga tanarius, Trema orientalis, Celtis sinensis, with a rapid rate of growth in the Taipei Basin and trees along urban roadsides, such as Bischofia javanica and Melaleuca leucadendra. In addition, pollen transported long-distance from high mountains, such as Cryptomeria, and entomophilous pollen occurred sometimes.

The relationship between sampling height and the concentration of collected airborne pollen has been studied previously (Raynor et al. 1973, Hart et al. 1994). Hart's group concluded that the pollen concentrations of Gramineae and Urticaceae from higher traps $(30 \mathrm{~m})$ were consistently smaller than those from lower traps (12 and $24 \mathrm{~m})$. In the present investigation, the trap was located on a nine-meter high building, and thus reliably collected relatively large amounts of NAP. However AP, such as Broussonetia, Trema and Bischofia, dominated during both years (Fig. 4, Fig. 5). NAP, such as Gramineae, and FS, such as Cyathea, were higher only in autumn. In this study, there was no control traps at ground level trap for purposes of comparison.

Many anemophilous plants produce enormous amounts of pollen grains (Faegri and Iversen 1975, Tormo et al. 1996), which are dispersed as pollen rain during the flowering season (Faegri and Iversen 1975). Furthermore, pollen of taller plants is easily released into the air (Faegri and Iversen 1975). According to previous investigations, pollen from trees predominated over that from herb and shrubs (ínceoglu et al. 1994). In this study, AP dominated not only in quantity but also in duration throughout the period. Miscanthus floridulus is the possible source of Gramineae in autumn because of it's taller main axis, (up to $1 \sim 2 \mathrm{~m}$, like a shrub). The tree-like Cyathea, with a trunk up to several meters, was the main source of FS. The succession of AP, NAP and FS (Fig. 5) in the atmosphere reflects the phenological patterns in Taipei.

\section{Main pollen seasons}

The two-seasonal incidence of airborne pollen in Taipei during 1993-1994 (Fig. 6), is similar to other areas in Taiwan (Peng and Chen 1997, Tsou et al. 1997) as well as areas, in India (Banik and Chanda 1992), Argentina (Majas and Romero 1992) and South Africa (Cadman et al. 1997). In fact, the pollen season is highly variable in different localities, and is influenced by geography and climate, which cause plants to have different vegetation and pollination periods. In Norway, there is one pollen season, (from April to September), and the composition of contributors is simple (Ramfjord 1991). In Italy, three main pollen seasons can be distinguished: winter-pre-spring, spring-summer and summer-autumn (Negrini and Arobba 1992). In Poland, collected pollen revealed a characteristic four-cycle pattern (Zawisza and Samolinska-Zawisza 1991).

In this study, the normal two quantitative peaks of pollen grains appeared in March and September in 1993, but not in 1994 (Fig. 6). In 'the latter year, heavy rain in February postponed the first pollen peak to April. After July, six 
typhoons brought heavy precipitation to northern Taiwan, so that no definite second peak appeared.

In 1993, the dominant pollen taxa during the two peaks were Broussonetia in March and Mallotus in September, respectively. In 1994, there was no definite second peak, but in September Mallotus was still the most frequent taxon. Broussonetia, Mallotus and other frequent contributors during pollen seasons, such as Trema, Morus, Bischofia in spring and Cyathea in autumn, are native species and are very common in Taipei.

\section{Pollen calendar}

The pollen calendars of Taipei in 1993 (Fig. 7) and 1994 (Fig. 8) are possible to illustrates the distribution of the airborne pollen types throughout the year.

In spring, AP are the most frequent pollen contributors. Morus pollen grains was recorded throughout the year and may be contributed by $M$. australis. It's main flowering season in spring, but the same period high concentrations of Broussonetia, Trema, Bischofia and Juniperus decreased the importance of Morus pollen in the air.

The highest concentration of Juniperus occurred in February 1994. Several cultivated species, such as J. chinensis var. kaizuka and J. chinensis var. pyramidalis, were possible sources of Juniperus pollen, (no attempts was made to distinguish individual species under LM). Beginning their flowering season in winter, they became important contributors in spring.

The flowering of male catkins of Broussonetia produced large amounts of pollen and then dispersed in the air to become the most common airborne pollen throughout the whole year. Significantly higher levels of Broussonetia pollen have been observed, not only in the Taipei Basin in this study, but also in other locations in Taiwan (Tsou et al. 1997, Peng and Chen 1997). The Broussonetia pollen seasons showed some variation during the two years in this study, and the first Broussonetia pollen season began distinctly later in 1994.

Bischofia pollen, found in large concentration, may include the common roadside tree, $B$. javanica, which flowers in spring.

The high concentration of Trema was recorded from spring to summer. Sources possibly included $T$. orientalis and $T$. virgata, which are common native species.

In summer, the most important sources were AP. FS also had begun to release but always less important than AP, except when Cyathea became dominant in summer later. The nearest possible source of Cyathea spores were three tree ferns, C. podophylla, C. spinulosa and C. lepifera, whose spores are difficult to distinguish under LM so were reported together. Cyathea has a tree-like stem with very large fronds, arranged in a terminal crown, and with sori borne on the backs of veins. The taller trunk of Cyathea easily releases spores into air and becomes a dominant source of airborne FS in Taipei.

Ardisia sieboldii, A. quinguegona and A. squamulosa are possible sources of Ardisia pollen in the air and are the dominant AP producer in June.
Mallotus pollen, found in summer and autumn, may be contributed by different plants, $M$. japonicus and $M$. paniculatus, whose main flowering seasons are in May and September, respectively.

Gramineae were frequently counted throughout the whole year and it was presumably caused by the successive flowering seasons of the various species. Oryza sativa, the main cultured crop in Taiwan is an important contributor of high concentrations of Gramineae pollen in June. Miscanthus floridulus is a possible source for the highest concentration of Gramineae pollen during October to December, NAP was dominant only in December.

There was a low concentration of airborne pollen and spores in winter, with the minimum in January.

Many pollen grains or fern spores may be found throughout the whole year, while others are restricted to rather short periods. Among the former, for example, Gramineae, Cyperaceae and Mallotus, represented different species flowering at different times and recording long airborne pollen seasons or secondary pollen seasons. Among the latter, for example, Fraxinus and Ambrosia showed a significantly shorter pollen season. Concentration of Ambrosia pollen rapidly decreasing in 1994, because of interruptions of the population along the banks of the Tan-Shui river.

Variations between the pollen calendars for the two individual years reflect the weather phenological climate and ecological data. However a long-term aerobiological survey is necessary to study the pollen calendar for effective use by an allergist.

\section{Ecosystem factors}

Broussonetia from many flowers of male catkin produces great amounts number of pollen grains during the flowering season and was the most frequent taxon during the period of study, constituting $27.7 \%$ of the total year sum in 1993 and $34.0 \%$ in 1994 . This contrasts with studies of New Flower Garden City (Tsou and Huang 1982) and the Tan-Shui area (Pen and Chen 1997), where the most frequent taxa were Gramineae and Broussonetia, constituting $33.8 \%$ and $73.7 \%$ of the year total, respectively. A different composition of contributors has been recorded at different locations, having different ecosystems (Satheesh et al. 1993). The vegetation of the New Flower Garden City, about $10 \mathrm{~km}$ from Taipei, has been subject to human intervention and pioneer plants have come up. For example, Miscanthus floridulus, which is very common in mountain areas, is the possible main source of airborne Gramineae pollen. The Tan-Shui, about $17 \mathrm{~km}$ northwestern of Taipei, is a harbor on the banks of the TanShui river, with simpler vegetation than Taipei and the New Flower Garden City. The highest contribution of Broussonetia pollen at the Tan-Shui area could be due to the Broussonetia papyrifera pure strands around the site of sampled airborne pollen.

Various authors have discussed forecast models on the basis of their airborne pollen concentrations (Subiza et al. 1991) and related weather conditions (Fehér and JáraiKomlódi 1997), especially at the beginning of the pollen. season (Arobba et al. 1992, Sahashi 1994). Regression 
analysis of airborne pollen concentrations for two years and climate factors for the same time periods used three weather parameters: mean temperature, precipitation and relative humidity.

The concentrations of airborne pollen in various months in 1993 and 1994 did not show a significant correlation $(r=0.24$, $p>0.05$ ), which could be affected by environmental factors. Our focus on the rainfall revealed that the different first pollen seasons in 1993 and 1994 were correlated with different weather types in February and July. In Taipei, the monthly average precipitation in spring during 1983 to 1992 were $175 \mathrm{~mm}$ (data from Central Weather Bureau). In particular, the lower precipitation (33.2 mm) in February in 1993 might have affected the beginning of the flowering season. After July 1994, six typhoons brought heavy precipitation to northern Taiwan and heavy rain might wash out airborne pollen (Berggren et al. 1995), so that no definite peak appeared in that time. In conclusion, the different weather types affected the timing of quantitative peaks in the two years studied.

This research was supported by the National Science Council of Taiwan, Republic of China, under grant NSC 82 0211-B-002-368-B08 and NSC 83-0409-B-002-005-B08. We would like to thank Ms. C.Y. Chang, Hondau Junior High School for providing a location for the trapping instrument.

\section{References}

Arobba, D., Imperiale, G. and Negrini, A.C. 1992. The main pollen season of Parietaria in Genoa (Italy)-forecast possibilities. Grana 31: 237-240.

Banik, S. and Chanda, S. 1992. Airborne pollen survey of Central Calcutta, India, in relation to allergy. Grana 31: 72-75.

Berggern, B., Nilsson, S. and Boethius, G. 1995. Diurnal variation of airborne birch pollen in some sites in Sweden. Grana 4: 251-259.

Cadman, A., Dames, J.F., Terblanche, P.S. and Nel, R. 1997. The AIRKEM study in Gauteng, South Africa: The role of the airspora in an industrial urban environment. Grana 36: 175-179.

Chen, S.H., 1988. A scanning electron microscope survey of common airborne pollen grains in Taipei. Taiwania 33: $75-108$.

D'Amato, G. and Liccardi, G. 1994. Pollen-related allergy in the European Mediterranean area. Clin. Exp. Allergy 24: $210-219$.

D'Amato, G. and Spieksma, F.T.M. 1990. An allergenic pollen in Europe. Grana 30: 67-70.

Fehér, Z. and Járai-Komlsymlódi, M. 1997. An examination of the main characteristics of the pollen seasons in Budapest, Hungary 1991-1996. Grana 36: 169-174.

Faegri, K. and Iversen, J. 1975. Textbook of Pollen Analysis, 3rd ed. revised. Munksgaad, Copenhagen.

Hart, M.L, Wentworth, J.E. and Bailey, J.P. 1994. The effects of trap height and weather variables on recorded pollen concentration at Leicester. Grana 33: 100-103.

Huang, T.C. 1972. Pollen Flora of Taiwan. Botany Depart- ment Press, National Taiwan University, Taipei.

Huang, T.C. 1981. Spore Flora of Taiwan. Botany Department Press, National Taiwan University, Taipei.

İnceoglu, Ö., Pinar, N.M., Sakiyan, N. and Sorkun, K. 1994. Airborne pollen concentration in Ankara, Turkey 1990 1993. Grana 33: 158-161.

Johansen, S. 1992. Aerobiological studies in subalpine birch forest at Doverfjell, Central Norway, 1982-1984. Grana 31: 131-142.

Majas, F.D. and Romero, E.J. 1992. Aeropalynology research in the Northeast of Buenos Aires Province, Argentina. Grana 31: 143-156.

Negrini, A.C. and Arobba, D. 1992. Allergenic pollens and pollinosis in Italy: recent advances. Allergy 47: $371-$ 379.

Norris-Hill, J. 1995. The modeling of daily Poaceae pollen concentrations. Grana 34: 182-188.

Peng, M. and Chen, S.H. 1996. Comparison of counting methods for the study of air-borne pollen with special reference to Broussonetia pollen. Taiwania 41: 35-42.

Peng, M. and Chen, S.H. 1997. Aeropalynological study in Taipei County (Tan-Shui), 1993. Taiwania 42: 117-134.

Pham, N.H., Baldo, B.A. and Bass, D.J. 1994. Cypress pollen allergy-identification of allergens and crossreactivity between divergent species. Clin. Exp. Allergy 24: 558-65.

Ramfjord, H. 1991. Outdoor appearance of aeroallergens in Noway. Grana 30: 91-97.

Raynor, G.S., Ogden, E.C. and Hayes, J.V. 1973. Variation in ragweed pollen concentration to a height of $108 \mathrm{~m}$. J. Allergy Clin. Immunol. 51: 119-207.

Rich, T.C.G. 1994. Ragweeds (Ambrosia L.) in Britain. Grana 33: 38-43.

Sado, M. and Takeshita, R. 1991. The seasonal variation of airborne pollen grains that cause sugi-pollinosis in Japan in the last three years. Grana 30: 282-289.

Sahashi, N. 1994. The pollen front of Cryptomeria japonica in 1994. Jpn. J. Palynol. 40: 55-64. [in Japanese with English summary]

Satheesh, R., Rao, G.R. and Nair, P.K.K. 1993. Aerial survey of pollen grains at two different altitudinal ecosystems of Tamil Nadu, India- a comparative study. J. Palynol. 29: 11-27.

Spieksma, F.T.M., Nikkels, B. and Dijkman, J. 1995. Seasonal appearance of grass pollen allergen in natural, pauci-micronic aerosol of various size fractions. Relationship with airborne grass pollen concentration. Clin. Exp. Allergy 25: 234 239.

Sriramarao, P. and Subba Rao, P.V. 1993. Allergenic cross-reactivity between Parthenium and Ragweed pollen allergens. Int. Arch. Allergy Immunol. 100: 7985.

Su, S.N., Lau, G.X., Lee, M.J., Shen, H.D. and Han, S.H. 1986. Isolation and partial characterization of allergen from Bermuda grass pollen. Chinese J. Microbiol. Immunol. 19: 263-275.

Subiza, J., Masiello, J.M., Subiza, J.L., Jerez, M., Hinojosa, M. and Subiza, E. 1991. Prediction of annual variations in atmospheric concentrations of grass pollen-a method based on meteorological factors and grain crop estimates. Clin. Exp. Allergy 22: 540-547. 
Tormo Molina, R., Muñoz Rodríguez, A., Silva Palacios, I. and Gallardo López, F. 1996. Pollen production in anemophilous trees. Grana 35: 38-46.

Tsai, Y.T., Chen, S.H., Lin, K.L. and Hsieh, K.H. 1990 . Rice pollen allergy in Taiwan. Ann. Allergy 65: 459-462.

Tsou, C.H., Tseng, I.J., Lin, R.F. and Hong, H.Y. 1997. Aeropalynological investigation in Taichung, Taiwan,
1993-1995. Bot. Bull. Acad. Sin. 38: 57-62.

Tsou, C.H. and Huang, T.C. 1982. Aeropalynological study of Taipei suburban. Taiwania 27: 9-30.

Zawisza, E. and Samolinska-Zawisza, U. 1991. Airborne pollen survey of the Warsaw area. Grana 30: 177-179.

(Received May 14, 1998: Accepted September 2, 1998) 